\title{
Assessment of human cytomegalovirus co- infection in Egyptian chronic HCV patients
}

\author{
Ashraf Tabll ${ }^{1 *}$, Sahar Shoman²* Hussam Ghanem², Mohamed Nabil ${ }^{2}$, Noha G Bader El Din ${ }^{1}$ and \\ Mostafa K El Awady ${ }^{1}$
}

\begin{abstract}
Human cytomegalovirus (HCMV) is the most common cause of severe morbidity and mortality in immunecompromised individuals. This study was conducted to determine the incidence of HCMV infection in HCV patients who either spontaneously cleared the virus or progressed to chronic HCV infection. The study included a total of eighty four cases (48 females and 36 males) that were referred to blood banks for blood donation with an age range of 18-64 years (mean age 37.62 \pm 10.03 years). Hepatitis C virus RNA and HCMV DNA were detected in sera by RT-nested PCR and nested PCR respectively in all subjects. Immunoglobulin G levels for HCV and HCMV were determined. Besides, IgM antibodies for HCMV infection were also determined in subjects' sera. Fifty three out of 84 cases (63\%) were positive for HCV-RNA while 31 (37\%) cases had negative HCV RNA. Forty six (87\%) and 13 (25\%) cases out of 53 HCV RNA positive patients were positive for HCMV IgG and IgM antibodies respectively. While 20 of 53 cases (38\%) had detectable HCMV DNA. To examine the role of HCMV infection in HCV spontaneous resolution, two groups of HCV patients, group 1) chronic HCV infection (positive HCV RNA and positive IgG antibodies) vs group 2) spontaneous resolution (negative HCV RNA and positive IgG antibodies) were compared. The percentages of positive CMV IgG and IgM results is higher in chronic HCV patient than those in spontaneously cleared HCV patients and the difference is highly statistically significant (P value $<0.001$ ). Also, there is a general trend towards elevated levels of CMV lgG antibodies in HCV chronic patients than those in spontaneously cleared HCV patients ( $P$ value $<0.02$ ). HCMV DNA detection in group 1 was more than twice the value observed in group 2 (38\% vs 14.3\%, P value < 0.001). Moreover, levels of liver enzymes were significantly higher in HCV RNA positive cases co-infected with HCMV DNA than HCMV negative cases ( $P$ value $<0.001$ ). The results indicate the role of HCMV in the liver pathogenesis. We conclude that chronic HCV patients co-infected with HCMV infection can be regarded as high risk groups for liver disease progression where they should be monitored for the long term outcome of the disease.
\end{abstract}

Keywords: Hepatitis C virus, Human Cytomegalovirus DNA, Co-infection

\section{Introduction}

The importance and the interest of HCMV as a pathogen have increased over the past two decades. Approximately $70-100 \%$ of the world's populations are carriers of the virus [1] and it has become the most common cause of severe morbidity and mortality in immune compromised individuals [2]. A primary HCMV infection is followed by a life-long persistence of the virus in a latent state, and

\footnotetext{
* Correspondence: ashraftabll@yahoo.com; karimbahaa2005@yahoo.com ${ }^{1}$ Department of Microbial Biotechnology, National Research Center, Giza, Egypt

2Department of Microbiology, Faculty of Science, Ain Shams University, Cairo, Egypt

Full list of author information is available at the end of the article
}

reactivation may occur later in life [3]. Therefore, reactivation of the virus is seen during periods of down-regulation of the immune system, such as drug treatment and illness-related stress, or during on-going activation of the immune system such as inflammatory diseases, or co-infection with other pathogens [4]. HCMV can infect virtually all organ tissues, but manifestations of organ involvement generally include symptoms from the liver, the lungs, the intestine and the CNS [5]. Cytomegalovirus is passed from person to person through close contact with body fluids, such as saliva, semen, vaginal fluids, blood, urine, tears and breast milk. Therefore, people can get CMV through sex, breastfeeding, blood transfusions
C Biomed Central

() 2011 Tabll et al; licensee BioMed Central Ltd. This is an Open Access article distributed under the terms of the Creative Commons Attribution License (http://creativecommons.org/licenses/by/2.0), which permits unrestricted use, distribution, and reproduction in any medium, provided the original work is properly cited. 
and organ transplants [6]. The cytopathic potential of HCMV in human liver cells was analyzed in cell culture and in tissue sections from patients with HCMV hepatitis, and it was concluded that HCMV can cause direct liver paranchymal damage by efficient cytolytic infection of hepatocytes [6,7]. Human CMV hepatitis occurs as part of disseminated CMV infection. It occurs mainly among liver or kidney transplant recipients or immunosuppressed persons [8,9], however many cases of CMV hepatitis in immunocompetent hosts have also been reported $[10,11]$ so that mild-moderately elevated levels of transaminases and various histopathological changes of the liver were encountered in these patients. On the other hand, HCV is a major health problem in Egypt $[12,13]$. We have recently shown that co-infection with HCMV could dramatically diminish the possibility of achieving SVR to peg IFN + RBV treatment in chronic HCV patients [14]. This study aims to investigate the incidence of co-infection of HCMV with HCV (either persistent or spontaneously cleared) in samples referred to several blood banks in Egypt.

\section{Material and methods}

Approval ethics

This research was approved by the Review Board of National Liver Institute, Menoufia University with reference number NLI 0003413 FW0000227

\section{Study population}

Eighty- four subjects who were referred to blood banks in Mansoura city (North Delta of Egypt) for blood donation during the period between February and May 2010 were enrolled in this study. The 84 cases included 48 females and 36 males, with age range 18-54 \pm mean of (37.62 \pm $10.03)$ years. Subjects were divided into two groups; patients who were positive for HCV IgG antibodies $(n=$ $67)$ and negative control group $(n=17)$ who were negative for HCV, HIV and HBV antibodies. Informed consents were obtained from each subject before collecting serum and whole blood samples. The age, sex, antibodies against HCV (anti-HCV IgG), antibodies against HCMV (antiHCMV IgM, anti-HCMV IgG), HCV RNA, HCMV DNA levels, and liver enzyme levels (ALT and AST) were assessed and recorded for both patients and controls.

\section{Detection of HCV IgG antibodies}

Serum samples were collected from all studied subjects to confirm the presence of HCV IgG Abs. HCV IgG Abs were detected using (Diagnostic Automation, INC 23961 Craftsman Road, Suite D/E/F, Calabasas, CA 91302, USA).

\section{Detection of HCV RNA in all samples}

Presence of $\mathrm{HCV}$ viremia was confirmed by reverse transcription-PCR using nested primers derived from the highly conserved 5' un-translated region. Serum samples were collected from all cases. Then RNA was extracted from $200 \mu \mathrm{l}$ of all serum samples using the acid guanidium thiocyanate-phenol-chloroform method [15]. Primer sets used in the detection of HCV RNA were as follow: P1: 5' GGTGCACGGTCTACGAGACCTC 3' P2 forward primer: 5' AACTACTGTCTTCACGCAGAA 3' - P3 reverse primer: 5' TGCTCATGGTGCACGG TCTA 3'- nested reverse primer P4: 5' ACTCGGCTAGCAGTCTCGCG 3' and nested forward primer P5: 5' GTGCAGCCTCCAGGACCC 3'. All primers were purchased from (Promega, Madison WI, USA). The nested PCR amplification was done in a volume of $50 \mu \mathrm{l}$; and the PCR protocol consisted of a reverse transcription step at $37^{\circ} \mathrm{C}$ for 60 min by using $20 \mathrm{U}$ of cloned Avian Myloblastosis Virus (AMV) reverse transcriptase, $1 \times$ buffer (supplied with the enzyme), (QBIOGENE, USA), 200-400 ng of total cellular RNA as template, 40 units of RNAsin (Clonetech, USA), $0.2 \mathrm{mmol} / \mathrm{l}$ from each dNTP (Promega, Madison, Wisconsin, USA) and 10 pmole from primer (P1). First round amplification was done on $10 \mathrm{ul}$ from the first cDNA strand synthesis reaction using 10 pmole from each of (P2) forward primer and (P3) reverse primer, $0.2 \mathrm{mmol} / \mathrm{l}$ from each dNTP (Promega, Madison, Wisconsin, USA), 2 units of Taq DNA polymerase (Promega, Madison, Wisconsin, USA) and $1 \times$ buffer supplied with the enzyme. The second round amplification was done similar to the first round, except for using the nested primers (P4) and (P5) as well as $10 \mathrm{ul}$ from the first round PCR product. Thermal protocols for both rounds were $1 \mathrm{~min}$. at $94^{\circ} \mathrm{C}, 1 \mathrm{~min}$ at $55^{\circ} \mathrm{C}$ and $1 \mathrm{~min}$ at $72^{\circ} \mathrm{C}$ for 30 cycles. The products of nested RT-PCR were analyzed on $2 \%$ agarose gel electrophoresis.

\section{Serological analysis of HCMV infection}

Human CMV IgM and IgG antibodies were detected in all samples by the qualitative ELISA test using commercially available CMV kits (BioCheck, Foster City, CA, USA). Tests were done according to the manufacturer instructions and results of HCMV IgM and IgG were expressed as O.D. units.

\section{Detection of HCMV DNA}

Total DNA was extracted from $300 \mu \mathrm{l}$ serum sample using Wizard ${ }^{\circledR}$ DNA purification mini kit, (Promega, Madison, Wisconsin, USA), following the instructions of the manufacturer. Human CMV DNA was amplified using primers derived from the $g B$ region of $C M V$ genome and PCR protocols were followed as described previously $[16,17]$. The amplification mixture contained $3 \mu$ of DNA extract, 10 pmole of each primer gB1: 5' GAGGACAACGAAATCC TGTTGGGCA 3' and gB2: 5' GTCGACGGTGGAGATACTGCTGAGG 3', $0.2 \mathrm{mmol} / \mathrm{l}$ from each dNTP (Promega, Madison, Wisconsin, USA), 2 units of Taq DNA 
polymerase (Promega, Madison, Wisconsin, USA) and $1 \times$ buffer supplied with the enzyme. Two ul from the $1^{\text {st }}$ PCR product were used in a nested-PCR containing the same conditions as mentioned above except for using nested primers gBn1: 5' ACCACCGCACTGAGGAATGTCAG 3' and gBn2: 5' TCAATCATGCGTTTGAAGAGGTA 3'. The thermal cycling protocol was as follows: $1 \mathrm{~min}$. at $94^{\circ} \mathrm{C}, 1 \mathrm{~min}$ at $55^{\circ} \mathrm{C}$ and $1 \mathrm{~min}$ at $72^{\circ} \mathrm{C}$ for 30 cycles. Nested amplification products were visualized on $2 \%$ agarose gel electrophoresis and stained with ethidium bromide.

\section{Liver Enzyme levels}

Alanine Amino Transferase (ALT) (normal range, $40 \mathrm{U} / \mathrm{L}$ ) and Aspartate Amino Transferase (AST) (normal range, $38 \mathrm{U} / \mathrm{L}$ ) levels were measured in all samples with commercial Kits (Siemens Healthcare Diagnostic Inc., USA) according to the manufacturer instructions.

\section{Statistical analysis}

All statistical analyses were performed using the SPSS 9.0 statistical software program. The statistical significance of difference was considered when $\mathrm{p} \leq 0.05$.

\section{Results}

\section{Prevalence of HCV IgG Abs and HCV RNA in studied subjects}

The results of HCV IgG Abs showed that 67 patients were positive for $\mathrm{HCV}$ IgG Abs while 17 were negative for $\mathrm{HCV}$ IgG Abs. The presence of $\mathrm{HCV}$ viremia was confirmed by RT-nested PCR. The RT-PCR products of HCV RNA in some subjects are shown in Figure 1. A result was considered positive when a clear 174-bp product was visible on agarose gel stained with ethidium bromide. In the sixtyseven patients who were positive for $\mathrm{HCV}$ IgG Abs, HCV RNA was detected only in fifty three subjects.

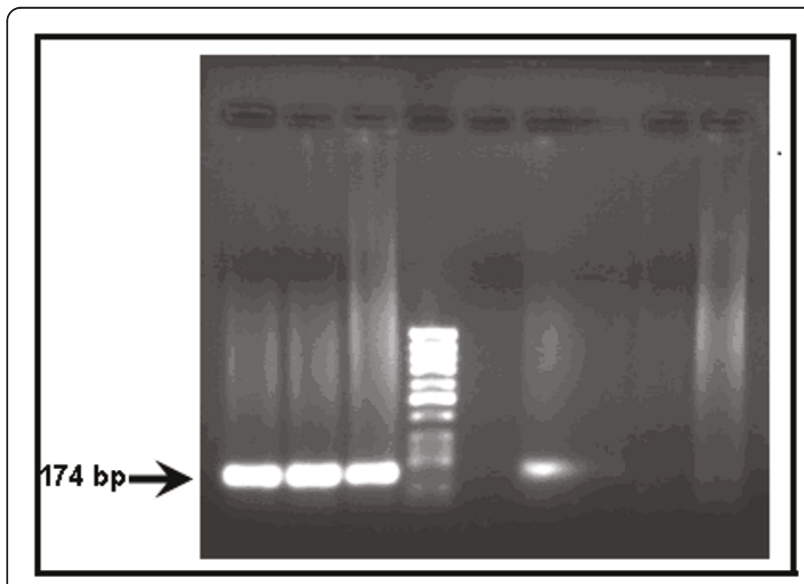

Figure 1 RT nested PCR results of serum samples lane 1, 2, 3 and 6 were positive for HCV RNA while lanes 5, 7, 8 and 9 were negative for $\mathrm{HCV}$.
Patients were classified according to the results of $\mathrm{HCV}$ IgG Abs and HCV RNA as follows: fifty three patients (31 females and 22 males) were positive for (both HCV RNA and HCV Abs) and they are described as group (1), while 31 cases (17 females and 14 males) were negative for $\mathrm{HCV}$ RNA. Among the later category (negative HCV RNA) 14 cases had detectable HCV IgG Abs (negative HCV RNA, positive $\mathrm{HCV}$ Abs) and were referred to as group (2) while 17 cases were negative for both HCV RNA and IgG Abs), and they are described as group (3).

\section{Prevalence of HCMV Abs in chronic HCV patients versus controls}

To investigate whether the prevalence of HCMV Abs (IgG and IgM) is higher in chronic HCV patients (group 1 ) than in comparable control subjects (groups 2 and 3), titers of both classes of immunoglobulins were measured in all subjects groups. Thirteen (25\%) and 46 (87\%) out of 53 chronic $\mathrm{HCV}$ patients (group 1) had detectable IgM and IgG HCMV Abs respectively. No gender preference was noted (6/13 males, 7/13 females were positive for HCMV IgM and 21/46 males, 25/46 females were positive for HCMV IgG). In group 2 (negative HCV RNA positive Abs) 2/14 (14.3\%) and 11/14 (78.6\%) were positive for HCMV IgM and IgG respectively. While in group 3 (negative for both HCV RNA and Abs), 3/17 (17.6\%) and 9/17 (53\%) were positive for IgM and IgG HCMV Abs respectively. The results depicted in Figure 2 showed that percentage of positive CMV IgG and IgM is higher in chronic HCV patients than those in spontaneously cleared HCV patients and the difference is highly statistically significant $(P$ value $<0.001)$. Results showed that

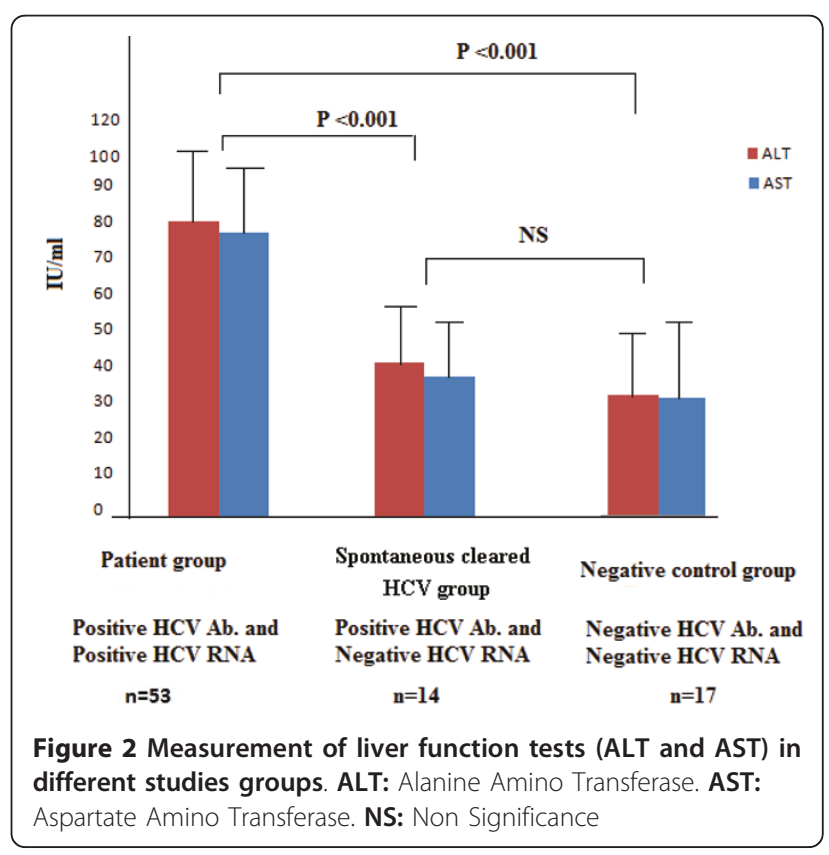


$25 \%$ of HCV patients had IgM vs $14.3 \%$ in controls (group 3) while $87 \%$ in chronic HCV patients had IgG HCMV Abs vs $78.6 \%$ in spontaneously cleared HCV patients (group 2). Also, there is a general trend towards elevated levels of CMV IgG antibodies in chronic HCV patients $(0.973 \pm 0.61)$ than those in spontaneously cleared HCV patients $(0.625 \pm 0.42)$, P value $<0.02$.

\section{Prevalence of HCMV DNA in chronic HCV patients versus controls}

The nested PCR product of CMV gB gene in some subjects is shown in Figure 3. A result was considered positive when a clear 100-bp product was visible on agarose gel stained with ethidium bromide. The results displayed in Figure 4 demonstrated that 20/53 (38\%) chronic HCV patients had detectable HCMV DNA in their sera, compared with 2/14 (14.3\%) of HCMV DNA positivity in group 2 (spontaneously cleared HCV infection group, negative RNA, positive $\mathrm{Ab}$ ) and 5/17 (29.4\%) in group 3 (control subjects, negative for both HCV RNA and Abs). Of the twenty positive HCMV DNA in chronic HCV cases 17 (85\%) had detectable HCMV IgG while 13 (65\%) only had detectable IgM with no gender preference. The observed difference between HCMV DNA prevalence in chronic $\mathrm{HCV}$ patients (38\%) and spontaneously cleared HCV patients (14.3\%) was highly statistically significant $(\mathrm{P}<0.001)$.

\section{Levels of ALT \& AST among study groups}

The results presented in Figure 2 clearly demonstrated a gradual decline in both ALT and AST levels from group 1 to group 2 and group 3. In HCV persistent group, serum ALT levels (mean: $82.7 \pm 20.6 \mathrm{IU} / \mathrm{L}$ ) and AST (mean: 79.2 $\pm 21.7 \mathrm{IU} / \mathrm{L}$ ). In spontaneously cleared group serum ALT mean levels were $42.9 \pm 9.8 \mathrm{IU} / \mathrm{L}$ ) and AST were $39.4 \pm$ $10.75 \mathrm{IU} / \mathrm{L}$ ) while in negative control group 3 where serum ALT mean levels were $33.6 \pm 10.7 \mathrm{IU} / \mathrm{L}$ and AST mean levels were $32.6 \pm 11.4 \mathrm{IU} / \mathrm{L})$. Serum ALT and AST levels were significantly higher in group 1 than in group 2 and group 3 ( $\mathrm{P}$ value $<0.001$ ) with no significant

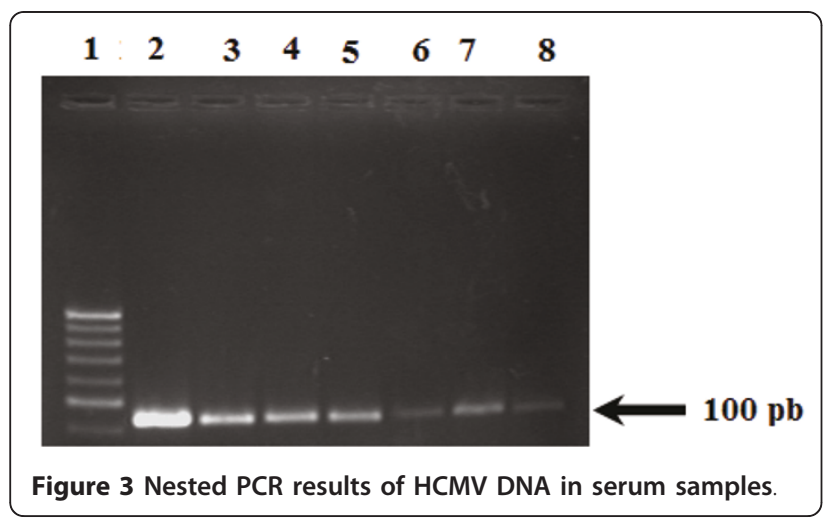

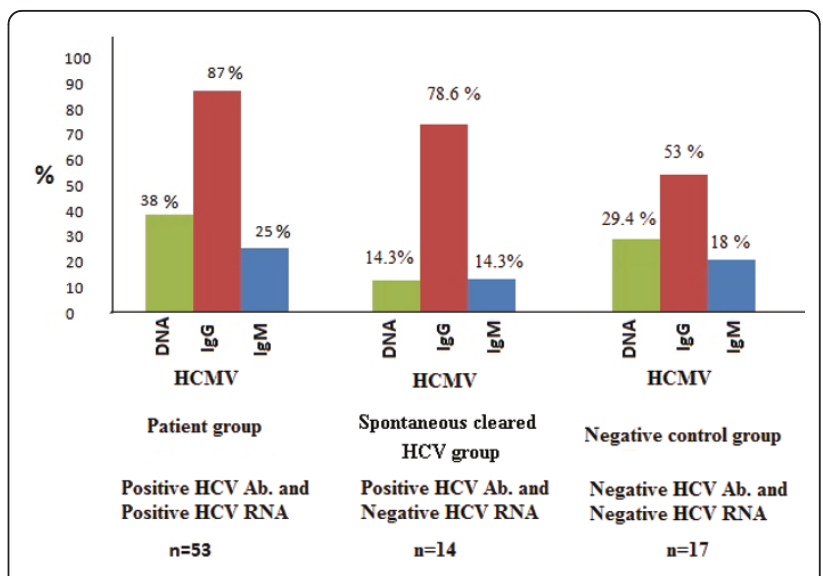

Figure 4 Detection of HCMV DNA, HCMV IgG and HCMV IgM antibodies the studied groups

difference between groups 2 and 3. Interestingly, in HCMV-positive chronic HCV patients, both ALT (mean: $93.2 \pm 24.9 \mathrm{IU} / \mathrm{L}$ ) and AST levels (mean: $90.2 \pm 24.6 \mathrm{IU} / \mathrm{L}$ ) were higher than that of $\mathrm{HCMV}$-negative chronic $\mathrm{HCV}$ patients where mean ALT values were $71.85 \pm 15.1 \mathrm{IU} / \mathrm{L}$ ) and AST were $70.5 \pm 16.9 \mathrm{IU} / \mathrm{L})$. The difference was highly statistically significant $(\mathrm{P}$ value $<0.001)$ as shown in Figure 5.

\section{Discussion}

Cytomegalovirus is a ubiquitous b-herpes virus that affects $60-80 \%$ of the human population. Infection with CMV is more widespread in developing countries. In general, HCMV infections are effectively controlled by the immune system, but without the ultimate clearance of the virus. Instead, the viral genome is retained at specific sites in a

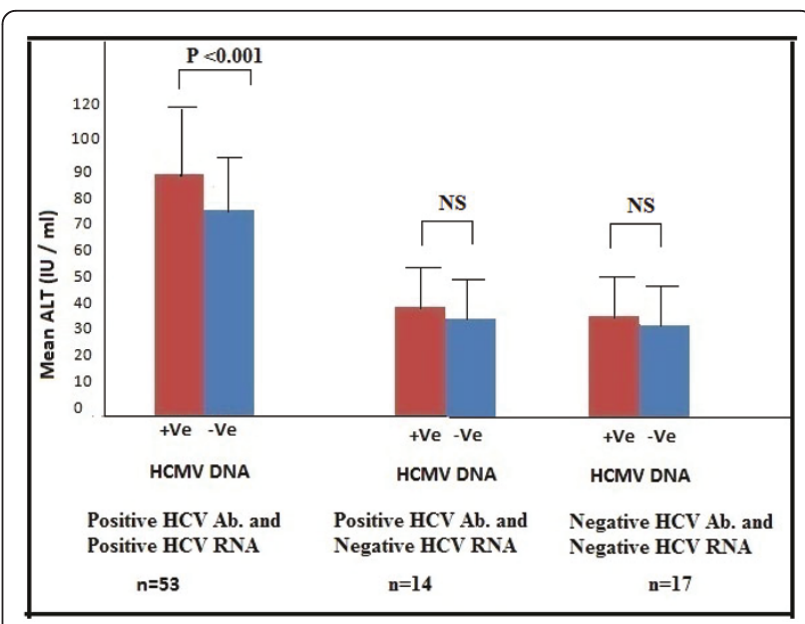

Figure 5 Measurement of ALT in patients positive and negative for HCMV DNA in the different studied groups. ALT: Alanine Amino Transferase. + Ve: Positive. -Ve: Negative. NS: Non Significance 
latent state out of which reactivation to recurrent infection can occur [18]. The diagnosis of active CMV infection was based on the detection of CMV replication in the blood. Therefore reactivation of CMV in the absence of an effective immune response is central to the pathogenesis of the disease [2]. In this study, we investigated the incidence of HCMV infection in Egyptian HCV patients who either spontaneously cleared the virus or progressed to chronic $\mathrm{HCV}$ infection and we examined the potential role that $\mathrm{CMV}$ plays in $\mathrm{HCV}$ progression. The present data showed that the percent of positive HCMV Abs were significantly higher $(\mathrm{P}<0.001)$ in chronic HCV patient than those in spontaneously cleared HCV patients. Also, the CMV DNA was detected in $38 \%$ of chronic HCV infected patients (65\% of them had positive IgM antibodies) compared with 2 out of 14 (14.3\%) spontaneously cleared HCV patients (where both patients had positive IgM antibodies). The percentage of positive CMV DNA results is higher ( $\mathrm{P}$ value $<0.001$ ) in chronic HCV patients compared to spontaneously cleared HCV patients, thus indicating a significant association between $\mathrm{HCV}$ progression rate and $\mathrm{CMV}$ reactivation. Moreover, the results confirmed that the detection of CMV DNA by PCR in peripheral blood leukocytes is a sensitive and reproducible procedure for detecting viral infection. As the serological methods reported to be insensitive and can't distinguish between CMV infection and CMV disease as IgM antibodies may persist for months or years and may be detected during reactivation of latent virus infections [19]. Recently, DaPalma et al., [20] classified virus-virus interactions by organizing them into three main categories: (1) direct interactions of viral genes or gene products, (2) indirect interactions that result from alterations in the host environment, and (3) immunological interactions, unique to organisms equipped with an adaptive immune system. In the present study the reason (s) why both HCMV IgM (17.6\% vs. $14.3 \%)$ and CMV DNA (29.4\% vs. $14.3 \%)$ were more frequently detected in healthy controls than in spontaneously cleared HCV subjects are not clear. However, we may suggest that virus-induced changes that may affect co-infecting viruses involve the innate immune mechanism induced by type I interferon known as the antiviral state. The antiviral state consists of increased expression of a combination of enzymes, which if activated, shut down cellular translation [21,22]. The most critical of these enzymes are PKR and 2'-5'OAS. In negative control group, $\mathrm{CMV}$ will replicate solely without the involvement of another virus i.e. HCV which explains the higher prevalence of CMV DNA in controls than spontaneously cleared $\mathrm{HCV}$ patients. In earlier studies on dual viral infections (HBV/CMV and HCV/CMV) $[6,23]$ it was demonstrated that $\mathrm{CMV}$ was detected in $\mathrm{HBV}$ or $\mathrm{HCV}$ patients mostly as a dual infection and that it can aggravate the course of the disease. Recently, Bader El din et al., [14] reported higher rate of CMV co-infection in chronic $\mathrm{HCV}$ Egyptian patients than those reported in other patient populations. Whether HCV predisposes patients to CMV infection or CMV predisposes patients to $\mathrm{HCV}$ is not clear. Besides, Lian et al., [24] reported a high mortality rate (85.7\%) in CMV and HBV co-infected patients compared to HBV infected patients only. Different studies reported that CMV causes hepatitis with inflammation and fibrosis of liver cells. That means CMV affects the liver and overall immunological status of the host body $[6,14,25]$. Bayram et al., [6] reported elevated liver enzymes and marked histological changes in the liver of HCMVHCV co-infected patients. The serum levels of ALT and AST enzymes showed a highly significant (P value < 0.001) elevation in positive HCMV DNA than in negative subjects, thus suggesting a role of HCMV in liver pathogenesis and support the results of Razonable et al., [26]. Furthermore, Rafael et al., [27] reported that HCMV infection interacted with $\mathrm{HCV}$ and raised the influence on the liver enzymes and cause hepatitis. Considering the fact that HCMV viruses exert an immunomodulatory effect resulting in enhanced immunosuppression $[28,29]$ and cytokine dysregulation which could accelerate HCV pathogenesis in critically ill patients, the findings of the present study support the hypothesis that even low level of HCMV replication doesn't evolve into clinical disease it significantly influences HCV outcome.

\section{Author details}

${ }^{1}$ Department of Microbial Biotechnology, National Research Center, Giza, Egypt. ${ }^{2}$ Department of Microbiology, Faculty of Science, Ain Shams University, Cairo, Egypt.

\section{Authors' contributions}

AT designed the study, wrote the final version of the manuscript. SS followed up all technical steps. HG followed up all technical steps. MN participated in extraction of DNA and RNA and PCR for HCV RNA and HCMV DNA. NB participated in writing the draft. ME finalized the manuscript in its final form. All authors read and approved the final manuscript

\section{Competing interests}

The authors declare that they have no competing interests

Received: 1 May 2011 Accepted: 10 July 2011 Published: 10 July 2011

\section{References}

1. Scholz M, Doerr HW, Cinatl J: Human cytomegalovirus retinitis: pathogenicity, immune evasion and persistence. Trends Microbiol 2003, 11(4):171-178.

2. Gandhi MK, Khanna R: Human cytomegalovirus: clinical aspects, immune regulation, and emerging treatments. Lancet Infect Dis 2004, 4:725-738.

3. Görzer I, Kerschner H, Redlberger-Fritz M, Puchhammer-Stöckl E: Human cytomegalovirus (HCMV) genotype populations in immunocompetent individuals during primary HCMV infection. J Clin Virol 2010, 48(2):100-103.

4. Gredmark S, Jonasson L, Van Gosliga D, Ernerudh J, Sderberg-Naucler C: Active cytomegalovirus replication in patients with coronary disease. Scand Cardiovasc J 2007, 41:230-234.

5. Cecilia S, Jay ANelson: Human Cytomegalovirus Latency and Reactivation A Delicate Balance between the Virus and Its Host's Immune System. Intervirology 1999, 42:314-321. 
6. Bayram A, Ozkur A, Erkilic S: Prevalence of human cytomegalovirus coinfection in patients with chronic viral hepatitis B and C: A comparison of clinical and histological aspects. J Clin Virol 2009, 45:212-217.

7. Sinzger C, Schmidt K, Knapp J, Kahl M, Beck R, Waldman J, Hebart H, Einsele $H$, Jahn G: Modification of human cytomegalovirus tropism through propagation in vitro is associated with changes in the viral genome. J Gen Virol 1999, 80(Pt 11):2867-2877.

8. Paya CV, Hermans PE, Wiesner RH, Ludwig J, Smith TF, Rakela J, Krom RA: Cytomegalovirus hepatitis in liver transplantation: prospective analysis of 93 consecutive orthotopic liver transplantations. J Infect Dis 1989 160(5):752-758.

9. Chan AY, Dieckhaus KD, Ramsey WH: Cytomegalovirus hepatitis in a nontransplant patient with autoimmune hepatitis taking immunosuppressants. Am J Gastroentero/ 2001, 96:262-263.

10. Kunno A, Abe M, Yamada M, Murakami K: Clinical and histologic features of cytomegalovirus hepatitis in previously healthy adults. Liver 1997, 17:129-132.

11. Miguelez M, Gonzalez A, Perez F: Severe cytomegalovirus hepatitis in a pregnant woman treated with ganciclovir. Scand J Infect Dis 1998 30:304-305.

12. Darwish NM, Abbas MO, Abdelfattah FM, Darwish MA: Hepatitis C virus infection in blood donors in Egypt. J Egypt Public Health Assoc 1992, 67(34):223-236.

13. Fallahian F, Najafi A: Epidemiology of hepatitis $C$ in the Middle East. Saudi J Kidney Dis Transp 2011, 22(1):1-9.

14. Bader el-Din NG, Abd el-Meguid M, Tabll AA, Anany MA, Esmat G, Zayed N, Helmy A, el-Zayady AR, Barakat A, el-Awady MK: Human cytomegalovirus infection inhibits response of chronic hepatitis-C-virus-infected patients to interferon-based therapy. J Gastroenterol Hepatol 2011, 26(1):55-62.

15. Chomczynski P, Sacchi N: Single-step method of RNA isolation by acid guanidium-thiocyanatephenol-chloroform extraction. Anal Biochem 1992, 162:156-159.

16. Fox J, Zuckermann M, Brink N, Neild PB, Gazzard G, Tedder R, Miller R: Detection of herpesviral DNA by nested polymerase chain reaction in CSF of HIV-infected individuals with neurological disease: a prospective evaluation. J Infect Dis 1995, 172:1087-1090.

17. Jones R, Lynne N, Beattie B, Westmoreland D, Fox J: Development and Application of a PCR-Based Method Including an Internal Control for Diagnosis of Congenital Cytomegalovirus Infection. J Clinical microbiology 2000, 38(1):1-6.

18. Söderberg-Nauclér C, Nelson J: Human Cytomegalovirus Latency and Reactivation - A Delicate Balance between the Virus and Its Host's Immune System. Intervirology 1999, 42:314-321.

19. Emery VC, Sabin C, Feinberg JE, Grywacz M, Knight S, Griffiths PD: Quantitative effects of valacyclovir on the replication of cytomegalovirus (CMV) in persons with advanced human immunodeficiency virus disease: baseline CMV load dictates time to disease and survival. The AIDS Clinical Trials Group 204/Glaxo Wellcome 123-014 International CMV Prophylaxis Study Group. J Infect Dis 1999, 180(3):695-701.

20. DaPalma T, Doonan BP, Trager NM, Kasman LM: A systematic approach to virus-virus interactions. Virus Res 2010, 149(1):1-9.

21. Galligan $\mathrm{CL}$, Murooka TT, Rahbar R, Baig E, Majchrzak-Kita B, Fish EN: Interferons and viruses: signaling for supremacy. Immunol Res 2006, 35(12):27-40.

22. Staeheli P: Interferon-induced proteins and the antiviral state. Adv Virus Res 1990, 38:147-200.

23. Shen CY, Chang BL, Chang SF, Yang SL, Tseng SL, Chen CY, Wu CW: Molecular epidemiology of cytomegalovirus infection in kindergarten children. J Med Virol 1996, 48(1):33-37.

24. Lian $Y$, Wu W, Shi Y: Preliminary study on relationship between different viral pathogenesis and disease prognosis in patients with severe viral hepatitis. Zhonghua Shi Yan He Lin Chuang Bing Du Xue Za Zhi 1999, 13(4):355-357.

25. Humar A, Kumar D, Raboud J, Caliendo AM, Moussa G, Levy G, Mazzulli T: Interactions between cytomegalovirus, human herpesvirus- 6 , and the recurrence of hepatitis C after liver transplantation. Am J Transplant 2002, 2(5):461-466

26. Razonable RR, Burak KW, van Cruijsen H, Brown RA, Charlton MR, Smith TF, Espy MJ, Kremers W, Wilson JA, Groettum C, Wiesner R, Paya CV: The pathogenesis of hepatitis $C$ virus is influenced by cytomegalovirus. Clin Infect Dis 2002, 35:974-981.
27. Rafael E, de la Hoz a, Stephens G, Christopher S: Diagnosis and treatment approaches to CMV infections in adult patients. J Clin Virol 2002, 25: S1-S12.

28. Lee SO, Razonable RR: Current concepts on cytomegalovirus infection after liver transplantation. World J Hepatol 2010, 27; 2(9):325-336.

29. Varani S, Landini MP: Cytomegalovirus-induced immunopathology and its clinical consequences. Herpesviridae 2011, 7; 2(1):6.

doi:10.1186/1743-422X-8-343

Cite this article as: Tabll et al:: Assessment of human cytomegalovirus co-infection in Egyptian chronic HCV patients. Virology Journal 2011 8:343.

\section{Submit your next manuscript to BioMed Central and take full advantage of:}

- Convenient online submission

- Thorough peer review

- No space constraints or color figure charges

- Immediate publication on acceptance

- Inclusion in PubMed, CAS, Scopus and Google Scholar

- Research which is freely available for redistribution

Submit your manuscript at www.biomedcentral.com/submit

Ciomed Central 